\title{
APPLICATION OF NEWLY SYNTHESIZED 8-HQ5-SAMF RESIN IN THE PURIFICATION OF WASTE WATER
}

\author{
R. N. Singru, ${ }^{1}$ V. A. Khati, ${ }^{2}$ W. B. Gurnule, ${ }^{3}$ A. B. Zade, 4 \\ ${ }^{1}$ Principal, Chintamani College of Science, Pombhurna, Chandrapur, India \\ 2 Department of Physics, Institute of Science, Nagpur, India \\ 3 \\ Department of Chemistry, Kamla Nehru College, Nagpur-440 009,India \\ 4 Department of Chemistry L.I.T. Nagpur-440 019, India \\ * Corresponding Author; Email: rajeshsingru@in.com.
}

Tel. 91-712-2750078, Cell: 9423122292, Fax: 91-0712-2747853

\begin{abstract}
Synthesized 8-HQ5-SAMF polymer resin in the laboratory and studied its ecofriendly chelating ion-exchange properties. In Chelating ion-exchange study metal ion uptake of resin was determined at three different variables such as different electrolytes and their different concentrations, different shaking time and different $\mathrm{pH}$ of the solution, for seven metal ions viz. $\mathrm{Fe}^{3+}, \mathrm{Cu}^{2+}, \mathrm{Ni}^{2+}, \mathrm{Co}^{2+}, \mathrm{Zn}^{2+}, \mathrm{Cd}^{2+}$ and $\mathrm{Pb}^{2+}$. 8-HQ5SAMF polymer resin is proved to be a eco-friendly cation exchange resin and can be used for the purpose of purification of environmental waste solution.
\end{abstract}

\section{Introduction}

The presence of heavy metals in the environmental area is a cause of concern. Removal of these metals has become increasing interest and need to have certain analytical technique $[1,2,3]$. Chelating ionexchange chromatography is one of the powerful techniques. Chelating ion-exchange has attained the status of unit operation in chemical industries. For chelating ion-exchange study organic ion exchange is chiefly of interest $[4,5,6]$. The present paper deals to explore synthesis, study of morphology and its eco-friendly ion-exchange property of 8HQ5-SAMF-III polymer resin.

The purpose of present study, is to explore the adsorption behaviour of seven metal ions $\mathrm{Fe}^{3+}, \mathrm{Cu}^{2+}, \mathrm{Ni}^{2+}, \mathrm{CO}^{2+}, \mathrm{Cd}^{2+} \mathrm{Zn}^{2+}$, and $\mathrm{Pb}^{2+}$ on the newly 
synthesized copolymer resins 8-HQ5-SAMF-III at different $\mathrm{pH}$ values, different concentration of different electrolytes and at different shaking time intervals. The adsorption behaviour of these metal ions is based on the affinity differences towards the chelating resins as functions of $\mathrm{pH}$, electrolyte concentrations and staking time. The copolymer resins under investigations are found to be cation exchanger having both ionexchange group and chelating group in the same polymer matrix and the resin can be used selectively for the purpose of purification of waste water. One of the important applications of chelating and functional polymer is their capability to recover metal ions from waste solution. Hence the chelating ion exchange property of the 8-HQ5-SAMF-III copolymer resin was also reported for specific metal ions [7, 8].

\section{Experimental}

\section{Synthesis of 8-HQ5-SAMF copolymer}

Copolymer 8-HQ5-SAMF was synthesized by condensing 8Hydroxyquinoline-5-Sulphonic Acid, melamine and formaldehyde in a mole ratio of $2: 1: 5$ in the presence of $2 \mathrm{M} \mathrm{HCl}$ as a catalyst at $140^{\circ} \mathrm{C}$ for 6 $\mathrm{h}$ in an oil bath. The structure of 8-HQ5-SAMF-III copolymer has been depicted in Fig.1. The purified copolymer was finally ground to pass through a 300 mesh size sieve and used in all experiments carried out in the ion exchange study.

\section{Ion-Exchange property}

\section{Experimental procedure:}

$25 \mathrm{mg}$ resin sample $+25 \mathrm{ml}$ electrolyte solution $+2 \mathrm{ml}, 0.1 \mathrm{M}$ metal nitrate solution, required $\mathrm{pH}$ was adjusted by $0.1 \mathrm{M} \mathrm{HNO}_{3}$ or $0.1 \mathrm{M} \mathrm{NaOH}$. The contents were stirred mechanically for $24 \mathrm{hrs}$ filtered and filtrate was titrated with standard EDTA solution with proper indicator (Experimental reading). Similar procedure was repeated without polymer (blank reading). 
Using this procedure, the metal ion uptake of 8-HQ5-SAMF polymer resin was determined for above seven metal ions at three different variables such as different electrolytes $\left(\mathrm{NaNO}_{3}\right.$ and $\left.\mathrm{Na}_{2} \mathrm{SO}_{4}\right)$ and their different five concentrations, different shaking time intervals and different $\mathrm{pH}$ of the solution.

\section{Determination of metal ion uptake at different electrolytes and their concentrations}

The above procedure was performed at two different electrolytes $\left(\mathrm{NaNO}_{3}\right.$ and $\left.\mathrm{Na}_{2} \mathrm{SO}_{4}\right)$, each with five different concentration $(0.01,0.05$, $0.10,0.50$ and $1.00 \mathrm{~mol})$.

Metal ion adsorbed (uptake) $=(\mathrm{X}-\mathrm{Y}) \mathrm{Z}$ millimols Determination of percentage metal ion uptake at different shaking time

The above procedure was performed at various shaking time intervals $(1,2,3,4,5,6$ and $24 \mathrm{hrs})$ by assuming $24 \mathrm{hrs}$ is the equilibrium state where maximum metal ions get adsorbed,

$\therefore \%$ metal ions uptake $=(\mathrm{X} .100) / \mathrm{Y}$.

Determination of metal ion uptake (distribution ratio) at various $\mathrm{pH} 1.5$ to 6

The above experimental procedure was carried out using $1 \mathrm{M}$ $\mathrm{NaNO}_{3}$ solution.

$\therefore$ Distribution ratio $(D)=z x / y \cdot 2 / 0.025$

Where, $\mathrm{X} g \mathrm{gm}=$ the amount of metal ion in $2 \mathrm{ml} 0.1 \mathrm{M}$ metal nitrate solution before uptake.

Y gm = the amount of metal ion in $2 \mathrm{ml} 0.1 \mathrm{M}$ metal nitrate solution after uptake.

$Z=$ Difference between actual experimented reading and blank reading.

$Z X=$ Amount of metal ion on resin; $2 \mathrm{ml}=$ Volume of aqueous metal nitrate solution

$0.025 \mathrm{gm}=$ Weight of resin in gram 


\section{Results and Discussion}

\section{Study of morphology by Scanning electron microscopy (SEM) - SEM}

micrographs were recorded at two different magnifications.

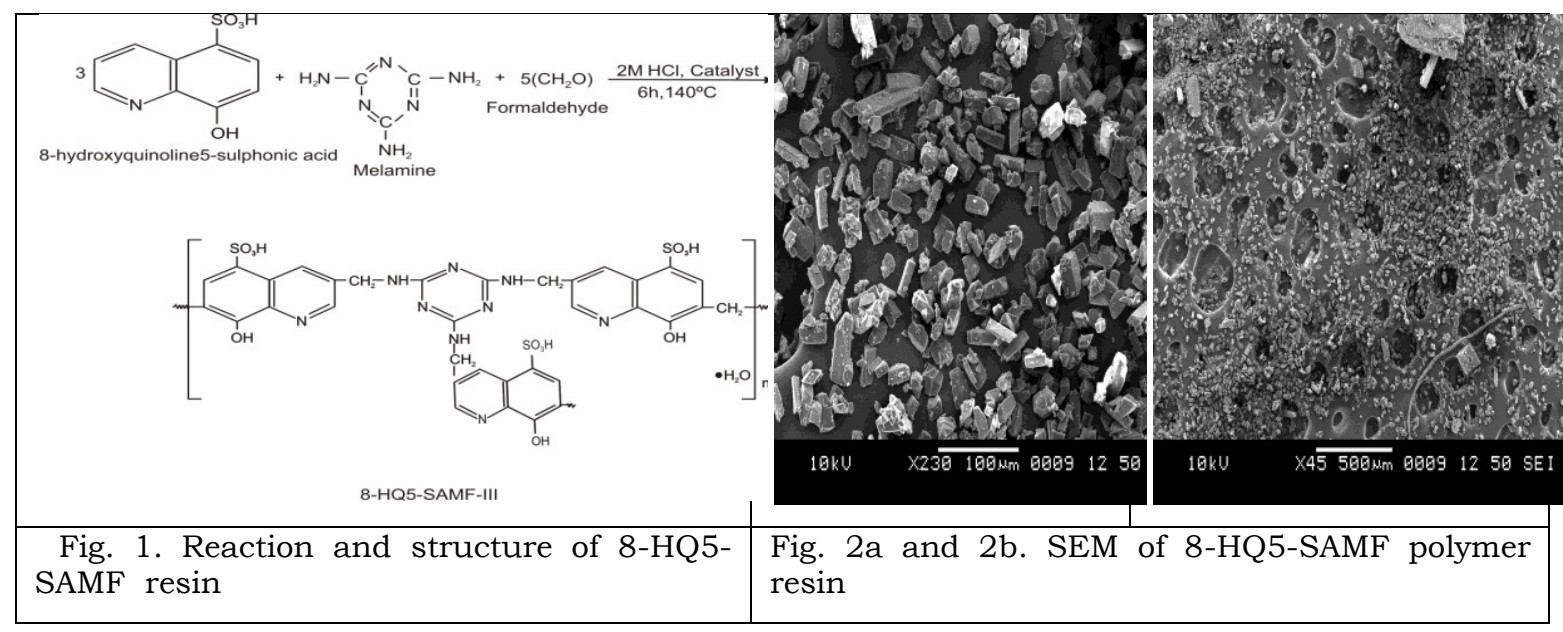

Fig.2a. Shows scattered particles nature i.e. spherulites which indicate the presence of crystalline nature. Fig. $2 b$. Shows fringed micelle model having shallow and deep pits on the surface which indicate the presence of amorphous nature.

Therefore SEM study shows transition structure between crystalline and amorphous nature. Amorphous nature indicates to show ionexchange property.

\section{Ion-Exchange property}

Effect of different electrolytes and their media of different concentrations on metal ion uptake:

$\mathrm{SO}_{4}{ }^{2-}$ forms strong complex with all metals as it is strong ligands. $\mathrm{NO}_{3}{ }^{-}$ forms strong complex with $\mathrm{Co}^{2+}, \mathrm{Zn}^{2+}, \mathrm{Cd}^{2+}$ and $\mathrm{Pb}^{2+}$ ions as $\mathrm{pH}$ is higher. $\therefore$ Polymer may difficult to break this complex, make metal ions free for adsorption $[8,9]$. $\therefore$ Metal ion decreases on increasing concentration.

While $\mathrm{NO}_{3}$ - form weak complex with $\mathrm{Fe}^{3+}, \mathrm{Cu}^{2+}$ and $\mathrm{Ni}^{2+}$ as $\mathrm{pH}$ is lower 
$\therefore$ Polymer may break this complex, can make metal ions free for adsorption. Hence metal ion uptake increases. (Fig.3)

\section{Effect of shaking time on percentage metal ion uptake:}

The graph shows that percentage metal ion uptake depends on shaking time and nature of metal ions. By increasing shaking time metal ion uptake increases but increase depend upon size of metal ions. Metal ion$\mathrm{Fe}^{3+}>\mathrm{Cu}^{2+} \approx \mathrm{Ni}^{2} \approx \mathrm{Co}^{2+} \approx \mathrm{Zn}^{2+}>\mathrm{Cd}^{2+} \approx \mathrm{Pb}^{2+}$ (Fig.4)
Ionic size -
0.52
0.61
0.690 .90
0.901 .10
1.19

$\mathrm{Fe}^{3+}$ require $3 \mathrm{hrs}, \mathrm{Cu}^{2+}, \mathrm{Ni}^{2}, \mathrm{Co}^{2+}$ and $\mathrm{Zn}^{2+}$ require $5 \mathrm{hrs}$ and $\mathrm{Cd}^{2+}$ and $\mathrm{Pb}^{2+}$ require $6 \mathrm{hrs}$ to attain equilibrium $[9,10]$.

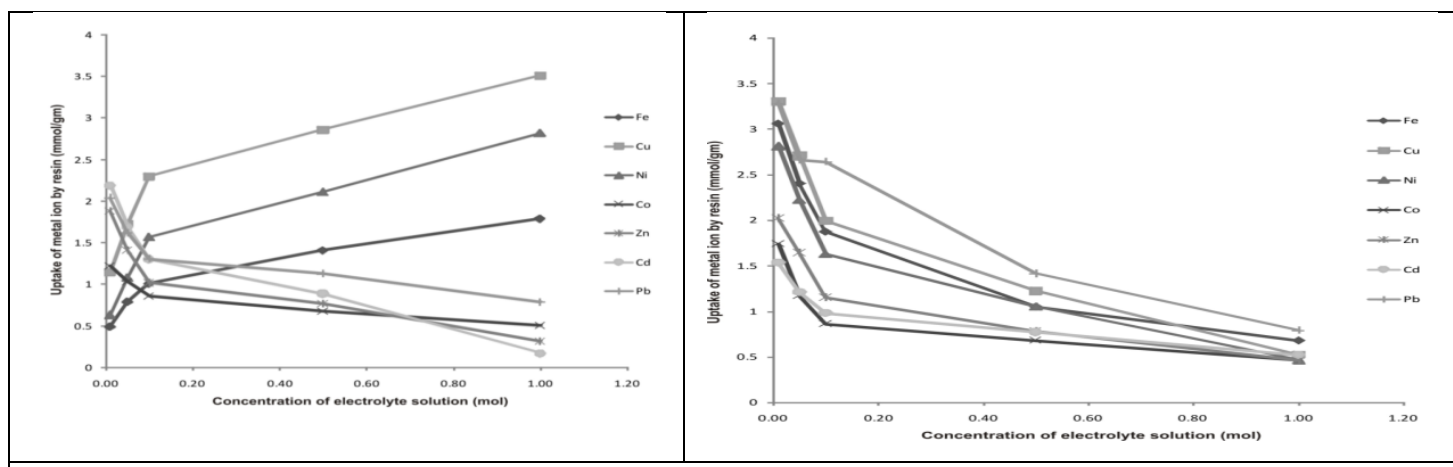

Fig. 3. Effect of concentrations of electrolytes a) $\mathrm{NaNO}_{3}$ and b) $\mathrm{Na}_{2} \mathrm{SO}_{4}$ ion metal ion uptake

complex.

$$
\text { Metal ion solution + electrolyte solution } \rightarrow\left[\text { Metal }-\mathrm{NO}_{3}^{-} / \mathrm{SO}_{4}^{2-}\right]
$$

\section{Effect of pH on distribution ratio}

The result shows that distribution ratio depends upon the $\mathrm{pH}$ of the solution. (Fig. 5).At lower $\mathrm{pH}$ (from 1.5 - 3) $\mathrm{Fe}^{3+}$ has highest distribution ratio, while at higher $\mathrm{pH}$ (from $3-6$ ) the $\mathrm{Cu}^{2+}$ and $\mathrm{Ni}^{2+}$ have higher distribution ratio rather than other metal cations which may be due formation of strong and stable complex between resin with metal ions. $\mathrm{Co}^{2+}, \mathrm{Zn}^{2+}, \mathrm{Cd}^{2+}$ and $\mathrm{Pb}^{2}$ form rather weak complex with resin therefore shows lower distribution ratios. The stability of complexes may depend upon various factors such as amphoteric nature of polymer 
resin, atomic number of ions, electrostatic factor, sterric influence, $\mathrm{pH}$ etc.

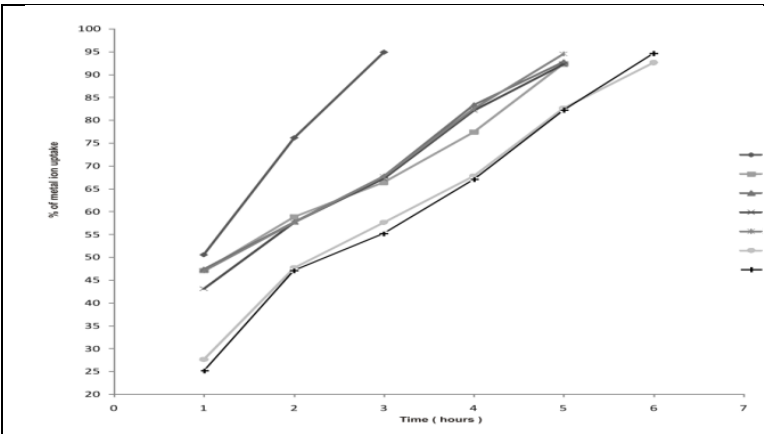

Fig.4. Effect of shaking time on \% metal ion uptake

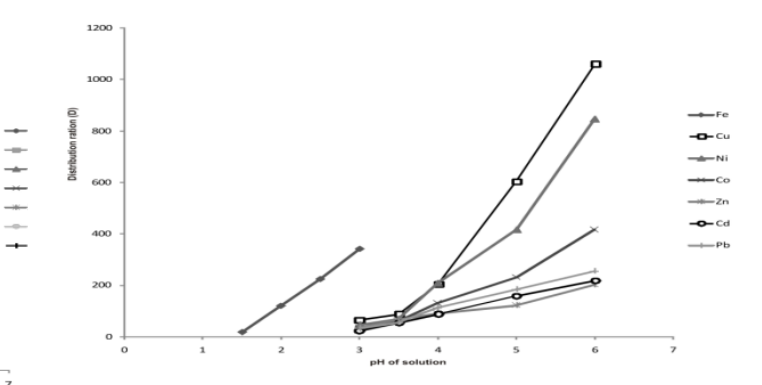

Fig. 5 : Effect of $\mathrm{pH}$ on the distribution ratio.

\section{Conclusion}

This study of ion-exchange reveals that 8-HQ5-SAMF polymer resin is proved to be a eco-friendly cation exchange resin and can be used for the removal of hazardous metal ions from the environmental area, for the purification of industrial waste solution and for the purpose of purification and desalination of water.

\section{References}

Dutta, S.; and Das, A. (2005) Ind J. Chem. Tech. 12, 139.

Lutfor, M. R.; and Silong S. (2000) Europ. Polym. J., 36, 2105.

Jadhao. M.; Paliwal, L. J.; and Bhave, N. S. (2005) Ind. J. Chem., 44, 225.

Patel, S. A.; Shah, B. S. and Patel, R. M. (2004) Iran. Polym. J., 13, 445.

Shah, B. A.; Shah, A. V. And Shah, P. M. E. (2008) J. Chem., 5, 291

Das S. C. (2000) J. Ind. Chem. Soc., 77, 69.

Rahangdale S. S.; Zade A. B. and Gurnule, W. B. (2008) J. Appl. Polym. Sci., 108, 747.

Tarase M. V.; Zade A. B. and Gurnule, W. B. (2008) J. Appl. Polym. Sci., $108,738$.

Singru, R. N.; Zade, A. B. and Gurnule, W. B. (2008) J. Appl. Polym. Sci., $109,859$.

Jadhao, M. M.; Paliwal L. J. and Bhave N. S. (2008) J. Appl. Polym. Sci., $10,508$. 